\title{
The Glans Schwannoma: A Rare Clinical Entity
}

Diallo Kadidiatou Folly ${ }^{1,2^{*}}$, Dyatta Mayombo Kévin ${ }^{1,2^{*}}$, Atsame Ebang Gabrielle ${ }^{3}$, Ipouka Doussiemou Sergina ${ }^{1}$, Nguele Ndjota ${ }^{1,2}$, Afoughe Mayombo Ornela Priscilia ${ }^{1}$, Mpira Yves Marien ${ }^{1,2}$

${ }^{1}$ Department of Visceral and General Surgery, University Hospital of Libreville, Gabon

${ }^{2}$ Department of Surgery, Owendo-Libreville University of Health Sciences, Gabon

${ }^{3}$ Biomedical Laboratory, Anatomical Pathology Unit, Libreville University Hospital, Gabon

Correspondence to: Diallo Kadidiatou Folly, University Professor, Department of Surgery, University of Health Sciences of Libreville, Gabon.

Dyatta Mayombo Kévin, General Surgery, University Assistant Professor, Department of Surgery, University of Health Sciences of Libreville, Gabon.

Received date: December 04, 2021; Accepted date: December 11, 2021; Published date: December 18, 2021

Citation: Diallo KF, Dyatta Mayombo K, Atsame Ebang G, et al. (2021) The Glans Schwannoma: A Rare Clinical Entity. J Med Res Surg 2(S1): pp. 1-3. doi: 10.52916/jmrs21S105

Copyright: (C2021 Diallo KF, et al. This is an open-access article distributed under the terms of the Creative Commons Attribution License; which permits unrestricted use; distribution and reproduction in any medium; provided the original author and source are credited.

\section{ABSTRACT}

Introduction: Schwannoma of the glans is a rare clinical entity. The diagnosis is histological. Treatment is surgical, with complete excision. The authors report this rare case encountered at the University Hospital of Libreville in order to identify its clinical and therapeutic characteristics.

Observation: Mr. I.B, 50 years old, with no medical-surgical history, consulted for swelling of the glans evolving for 06 years, preventing coitus. He reported a notion of poor healing from an acorn sore after the trouser fly was closed. The diagnostic suspicion was a glans keloid. A complete resection was performed. Histologic examination favored a glans schwannoma. Healing was effective on D7 postoperatively. Erectile functions have been preserved.

Conclusion: The glans schwannoma is rare. Surgical treatment gives good results.

\section{Keywords:}

Schwannoma, Glans, Surgery, Libreville.

\section{Introduction}

The schwannoma is a benign tumor of ubiquitous localization. Its localization in the glans is a rare clinical entity [1]. Very few cases have been collected in the literature. The authors report this rare case encountered at the University Hospital of Libreville in order to identify its clinical and therapeutic characteristics.

\section{Patient ET Observation}

Mr. I.B, 50 years old, without a notorious medical-surgical history, consulted for progressive swelling of the glans developing for 6 years, preventing coitus (Figure 1).

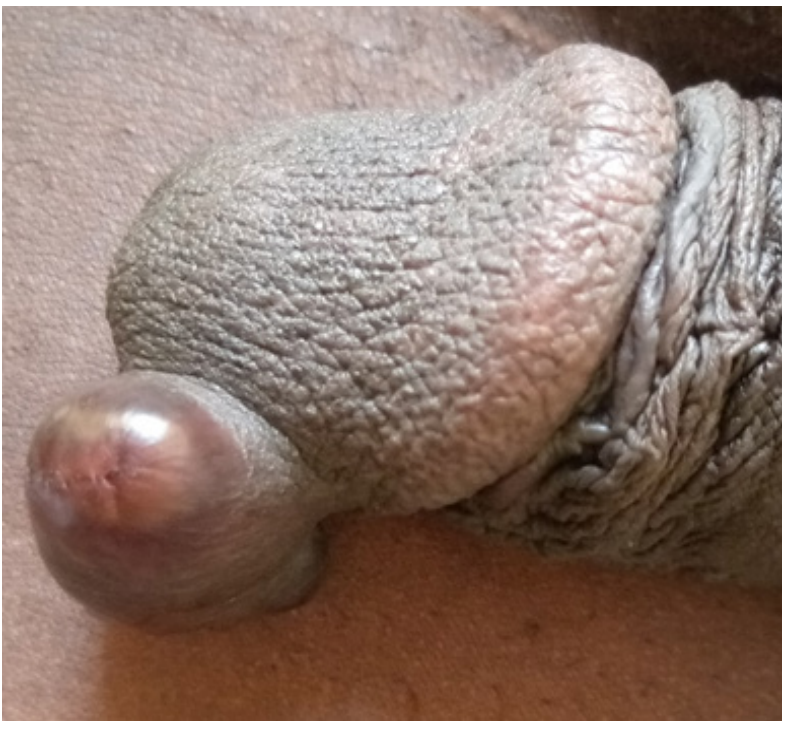

(A)

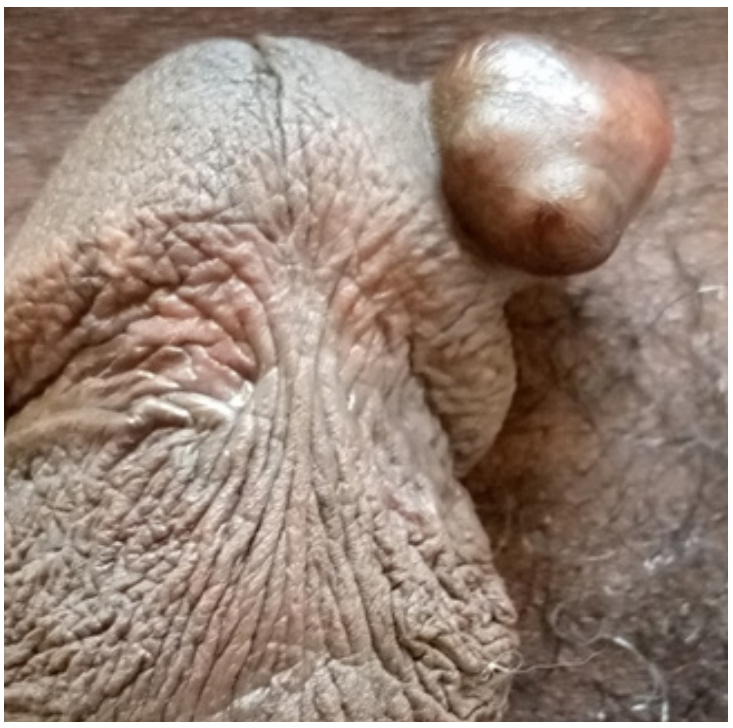

(B)

Figure 1 (A and B): Preoperative view. Polylobed nodule, firm, unique lower left of the glans penis.

The patient reported a notion of poor healing following an injury to the glans after closing the trouser fly. The patient was in good general condition. The examination found a painless nodule measuring $20 \times 25 \mathrm{~mm}$, at the level of the left ventrolateral part of the glans. The inguinal lymph node areas were free. The diagnostic suspicion was a benign keloid-like tumor of the glans primarily from clinical history without ruling out a malignant tumor. The abdominal ultrasound, performed to look for deep lymphadenopathy, was normal. A large resection was performed. Histological examination was in favor of a glans schwannoma (Figure 2). 


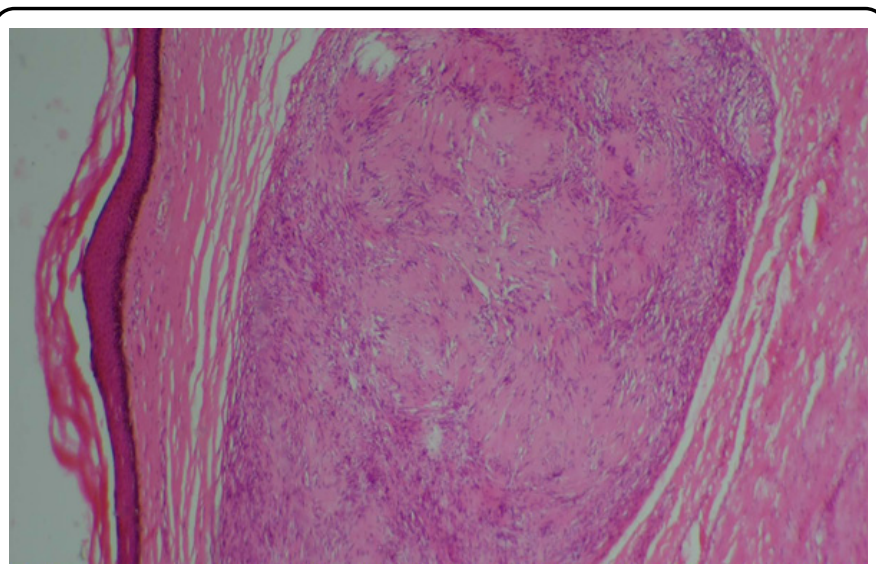

Figure 2: Microscopic view. Skin tissue in which the dermis contains a nodule that has areas $A$ of Antoni with nuclear palisades and areas B of Antoni in favor of a schwannoma (low magnification).

The overall progress was satisfactory, healing was effective on D7 postoperatively (Figure 3 ). Erectile functions have been preserved. The patient resumed normal sexual activity after one month. There was no recurrence after 1 year follow-up.

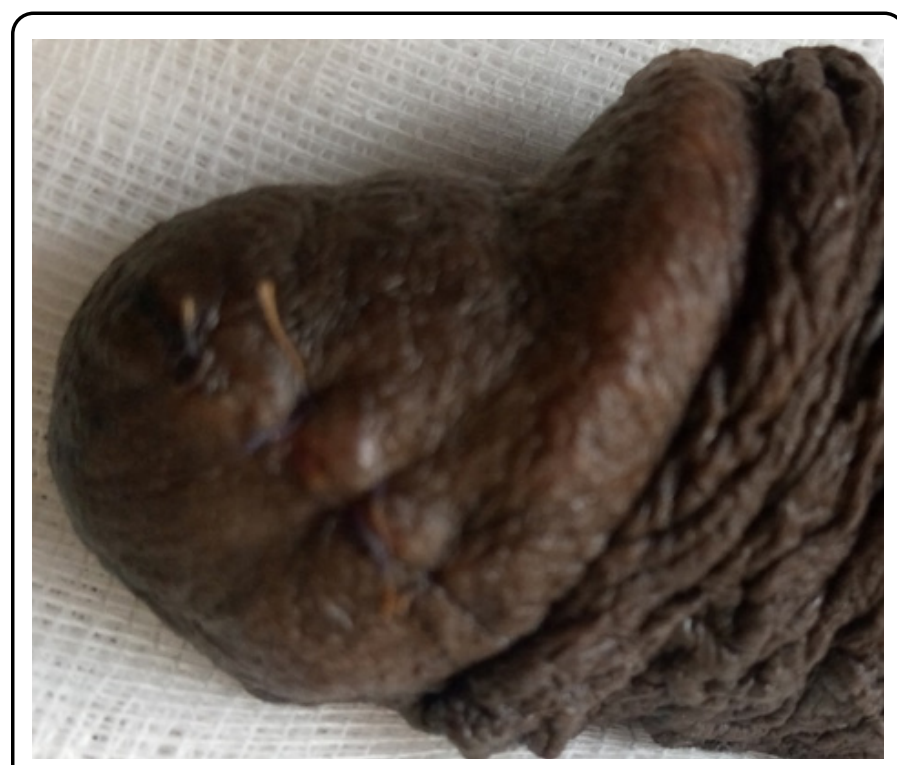

Figure 3: Post-operative view. Operative scar of the glans after excision of the nodule.

\section{Discussion}

Schwannomas are tumors that develop from the nerve sheaths (Schwann cells). They can occur sporadically in patients with neurofibromatosis and can affect any part of the body with a predilection for the head, neck and anterior aspect of the extremities $[2,3]$. Its localization on the penis is extremely rare [2]. It is a benign tumor [4]. Patients consult for a progressive increase in penile swelling $[5,6]$ or a disorder during intercourse [1] as described in the observation. These tumors occur at any age and mainly between 30 and 60 years $[1,5-8]$. The differential diagnosis must be made with all benign or malignant tumors of the penis including the keloid of the penis. The keloid is a pathological scar on the human skin or cornea. It is defined as a fibrous proliferation of dermal origin with root extensions in the shape of "crayfish pincers" which have been evolving for more than two years [9]. Black African subjects and Asians are more prone to developing keloids [10] and is a public health subject in high risk countries [11]. The etiologies of keloid penis are circumcision and other surgical procedures and traumatic injuries [12]. In the observation, it was a trouser fly injury that occurred 06 years earlier, secondarily causing a swelling gradually increasing in size. This progressive evolution of the lesion over the long term without alteration of the general condition or lymphadenopathy and the macroscopic appearance argued in favor of a benign keloid-type tumor of the glans, having motivated the indication of a first surgical excision. Faced with a tumor of the glans in predisposed subjects and depending on the context, the keloid appears and is therefore a differential diagnosis of schwannoma of the glans.

The treatment of glans schwannoma is surgical based on complete excision of the tumor nodule $[1,5,6]$, if possible with an extemporaneous histological examination to confirm the healthy character of the section edges. The size of the tumor and the lateral location of the tumor facilitated the surgery in the observed case.

Any surgical specimen should benefit from a histological examination. Histological examination plays a significant role. It will make it possible to make the diagnosis of schwannoma of the penis on the one hand but also and to eliminate all other differential diagnoses on the other hand. There are two types of architectures. Compact areas of spindle-shaped cells, with eosinophilic cytoplasm arranged in palisades (Verocay's nodules) and rolls, corresponding to areas of Antoni A. Areas of rare tumor cells in myxoid tissue called areas of Antoni B [3]. Both architectures were found simultaneously in the observation described. When immunohistochemistry is performed, the staining is positive for the S-100 protein, showing the nerve origin of the tumor [13]. The inability to perform this specialized examination in our context is related to the absence of this technology. The possibilities of diagnosis outside the borders are possible but depend on the conditions of the patients because they have to bear the high cost of this examination.

The post-operative consequences are generally simple in the case of a benign tumor, more precisely of a schwannoma. The patient returned to normal sexual activity after one month, with no observed disturbances. Recurrence and malignant degeneration are rare $[1,5-7]$. Clinical monitoring of this patient should continue for a minimum of 2 years.

\section{Conclusion}

Schwannoma of the glans is a rare benign tumor, diagnosed histologically. Treatment is surgical, focused on complete tumor excision. Short-term results are satisfactory and recurrence is rare.

\section{Ethical Considerations}

The authors have obtained patient consent and clearance from the appropriate medical authorities before writing this work.

\section{Funding}

None.

\section{Conflict of Interest}

The authors declare no conflict of interest. 


\section{References}

1. Mejri R, Dali KM, Chaker K, et al. 2022 Isolated penile schwannoma : a rare case report. Urol Case Rep 40: pp. 1-3.

2. Stout AP 1935 The peripheral manifestations of the specific nerve sheat tumor (neurilemmoma). Am J Cancer 24(4): pp. 751-796.

3. Cotran RS, Kumar V 2005 Peripheral nerve sheat tumors. In : Robins and Contran pathologic basis of disease. (7thedn), Saunders Elsevier, Philadelphia: pp. 1411-1413.

4. Mayersak JS, Viviano CJ, Babiarz JW 1995 Schawannoma of the penis. J Urol 153(6): pp. 1931-1932.

5. Essatara Y, Benazzouz MH, Sami R, et al. 2014 Le schwannome pénien : à propos d'un cas. PAMJ 18: pp. 1-3.

6. El Harrech Y, Ghadouane M, Ammani A, et al 2006 Schwannome du pénis (à propos d'une observation). Afr J Urol 12(2): pp. 109110.

7. Kumar U, Kishore Jha N 2017 Schwannoma of the penis, presenting as a scrotal mass, rare entity with an uncommon presentation. Urol Ann 9(3): pp. 301-303.

8. Algaba F, Chivite A, Rodriguez-Villalba R, et al. 2003 Schwannoma of the penis : a report of 2 case. J Androl 24(5): pp. 651-652.

9. Kadio M, Dick R, Malan E, et al. 1990 Exérèse intrachéloïdienne et infiltration différée de corticoïde dans le traitement des chéloïdes. Med Trop 50: pp. 279-285.

10. Datubo-Brown DD 1990 Keloids : a review of the literature. Br J Plast Surg 43: pp. 70-77.

11. Allah KC, Yéo S, Kossoka H, et al. 2013 Cicatrices chéloïdes sur peau noire : mythe ou réalité. Ann Chir Plast Esth 58: pp. 115-122.

12. Mastrelorenzo A, Rapaccini AL, Tiradritti L, et al. 2003 A curious kloid of the penis. Acta Derm Venereol 83: pp. 384-385.

13. Lin TC, Wu PY, Lin TY, et al. 2010 An infrequent plexiform variant of schwannoma of the glans penis: a rare finding. Asian J Androl 12(3): pp. 455-457. 